\title{
Enhancement of Site Managers Efficiency towards Accomplishments of Project Objectives
}

\author{
Fapohunda, J. A. \\ Yaba College of Technology, Department \\ of Building Technology, Yaba, Lagos State, \\ Nigeria \\ bldrfapo@yahoo.com
}

\author{
Omoniyi, S. S \\ Department of Architecture, Olabisi \\ Onabanjo University, Ago Iwoye, Ogun \\ State, Nigeria \\ unbeatableng@yahoo.com
}

DOI 10.5592/otmcj.2011.2.4 Research paper

\section{Keywords}

Construction production process, Project

Concepts, Site Managers

Objectives, stakeholders' satisfaction, Resources Utilisation

A CONSTRUCTION PROJECT COULD BE COMPLETED WITHIN THE BUDGETED COST; TIME FRAME; QUALITY EXPECTED, AND, EVEN SATISFIED THE STAKEHOLDERS' IMPLIED NEEDS WITH LOTS OF RESOURCES WASTAGE, THUS, AN ACCOMPLISHMENT OF THE PREDETERMINED PROJECT OBJECTIVES DO NOT SIGNIFY THAT THE PROJECT IS SUCCESSFUL IN UTILISATION OF RESOURCES OPTIMALLY. To achieve optimal construction resources utilisation and minimisation of resources wastefulness, in addition to other factors; there is a need to assess how the site manager's achieve the project concepts in relation to the resources utilisation, which this study evaluated. This research was conducted in the UK and mixed method research approach was adopted by exploring quantitative questionnaire and qualitative interview surveys' methods for obtaining data. The paper establishes factors that are under accomplished by the site manager and which require improvement towards optimal resources utilisation. Among the facts deduced are the needs for effective management of time and cost saving contrasts; implementation of prefabrication, modular construction systems; and adequate planning before project commences. The findings report in this paper will not only enhance the site managers efficient performance during construction production process, but will also improve resources utilisation and stakeholders' satisfaction.

\section{INTRODUCTION}

$P$ Management of projects has a specific set of objectives and constraints with a time frame for completion as identify in much literature including Hendrickson (2009) and Wideman (1986). This distinguishes management of construction project from the general management of corporations; its mission-oriented nature, which is terminated when the mission has been accomplished, (Blair, 1993; McGeorge and Palmer, 2002; and Haughey, 2009). Though, the management of all projects have much in common; however, the relevant technology, institutional arrangements and processes differ.

The perception of which this research paper is based is that: Accomplishment of the predetermined project missions does not signify that the typical project is efficiently successful in resources utilisation; a project could be completed 
within the budgeted cost; time frame; quality expected, and, even satisfied the stakeholders' implied needs with lots of resources wastage. Egan (1998) indicated that the industry is under achieving and detailed the significant needs of re-engineering the construction production process; achievable by rethinking the procedure of which the construction products are being delivered. These will improve stakeholders' satisfaction, organisation profits and construction resources' wastes management.

Among the key roles of a site manager on project site is to carefully plan construction production process with resources available, and to deliver the project successfully. To accomplish these project objectives timely, within budgeted cost and to quality required, there are needs to adequately develop the project plan, define project goals and specify the tasks involved, and match these with the project predetermined objectives, as stressed in PMI (2005), and APM (2006). Also, the manager has to address from the outset how project concepts will be achieved; what resources are needed and the associate budget and timeline available, (Wideman, 1996). The site manager has to implement the project plan; ensure that the project tasks run within "critical path" as predetermined; and ensembles all activities, (tasks) that are concerned with successfully achieving the set goal of the project. In addition, the site manager should strive to maintain mutual interaction of project participants from initiation to hand-in over; in such a way that overall risk of failure is reduced, (Hillson and Murray - Webster, 2005; and Rafele, et al., 2005), and optimal objective is achieved, (Newcombe et al., 2003). Thus, the requirements towards successfully achieving the set goal of the project by the site management necessitate for effective planning, scheduling and maintaining progress of all the project activities; adequate definition of the project targets; and optimisation of the use of available resources for the project product(s) delivery.

Most of the construction products are required to be delivered within scope, on time and at minimum cost, and to meet the set project quality benchmark, (PMI, 2005; APM, 2006; and Haughey, 2009), illustrated in the classic scope, time, cost and quality triangle, (Haughey, 2009), Figure 1.1. A project is considered to be effectively implemented when the project is delivered and satisfies customers' expectations, Figure 1.2. Though, there are no two customers' expectations that are same, and it is difficult to measure the level of the satisfaction; however, at any project completion, the majority of customers' expectations need to be significantly met.

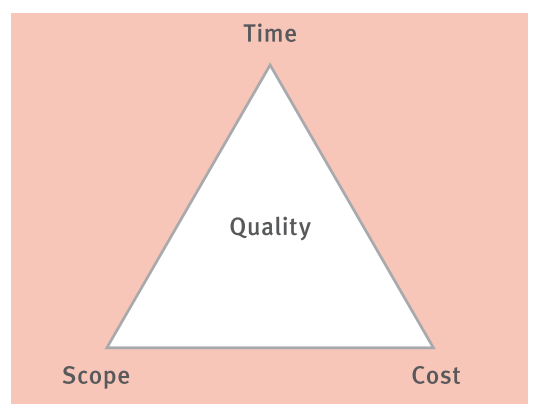

Figure 1.1 Project's Delivery Objective Triangle (Modified from Haughey (2009))

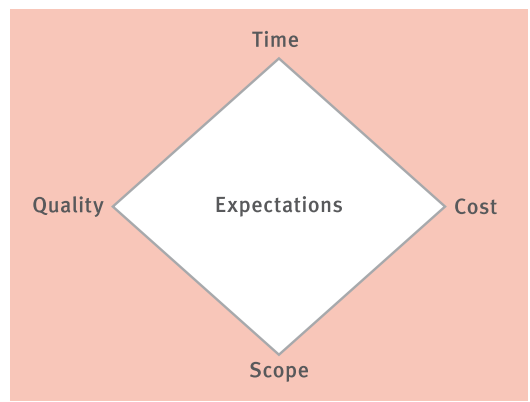

Figure 1.2 Stakeholder Expectation Diamond (Modified from Haughey (2009))

Noteworthy, if there is unlimited money and time for a project, management of such project becomes easier, but several projects have either or both time and cost constraint(s). The efficient time and cost integration management are paramount for project success. while the Site manager is required to deliver project to customer quality requirements, as these are important factors to measure a site manager efficiency, and the project success.

To achieve optimal resources utilisation and accomplish an enhanced construction project objective, there is a need to examine the characteristics of the construction site managers knowledge, attitudes and perceptions, (KAP) towards the accomplishment of the predetermined project objectives; to establish the factors that are under accomplished, and which require more attention towards optimal resources utilisation. This study thus investigates and establishes the factors that are required to be accomplished by the Site managers in order to minimise resources' wastes that will enhance resources utilisation and perpetuate stakeholders' satisfaction during construction production process.

\section{Research Method}

This research establishes the factors that will enhance the accomplishments of project objectives by the construction site managers during the production process. The research was conducted in the UK. Mixed method research approach was adopted by exploration of quantitative questionnaire and qualitative interview research methods for the data and information collection. The rationales of adoption of mixed method are for triangulation purpose and to enhance the achievement of valid and reliable findings; the demerits of one approach will negate the other one. The views of Sapsford and Jupp (1996), Sapsford (1999), Silverman (2000), Sarantakos (2001), Coakes and Steed (2003), Bryman and Cramer (2005), and Field (2005) guarded the effective implementation of the qualitative interview and quantitative research methods. 
The factors considered in this paper were grouped into twelve, (12): materials, manpower, machinery, quality in construction, construction resources cost, time management, risk in construction, resources procurement, project scope determination, delegation of authority, nominated suppliers and sub contractors monitoring and control.

The questionnaires survey respondents rated the factors enlisted on "ease of accomplishment" during construction production process. The factors are rated on Likert scale of (0) to (4); where "very high accomplishable" is represented by (4) and "not accomplishable" is denoted with (o). Also, the respondents categorised each factor as either "a desirable" or "an essential" factor towards efficient construction resources utilisation. One hundred and two, 102 completed questionnaires were collected, collated, and analysed using Statistical Package for the Social Sciences, (SPSS) statistics software.

Further investigations were carried out through exploration of qualitative interview survey to ascertain the findings obtained during questionnaires survey: for triangulation purposes and to enhance the reliability and validity of the questionnaires survey research findings. Eight site managers were interviewed, and all the participants have not less than fifteen years work experience as a manager in different multinational construction organisations. The following questions were addressed during the interview survey research:

a) What are the factors that will significantly enhance the accomplishments of site managers' propositions during construction production process?

b) Based on the results of questionnaires survey, the accomplishments of several site managers' propositions are highly achievable; then why are lots of resources' wastes during construction production process?
The information obtained from the interview survey was tape recorded with digital audio recorder, uploaded to computer, transcribed, coded, analysed and the emergence themes were collated using NVivo statistics software.

The inferences and deductible facts from quantitative and qualitative research surveys are presented in section 3.0

\section{Data Presentation and Discussion of Findings}

\section{Quantitative Questionnaires Survey}

This sub - section presents the quantitative questionnaires survey research data collected, data analyses and the inferences deduced.

\section{Ease of accomplishment of site} management propositions

The ease of accomplishment of these factors were grouped, rated, and ranked as illustrated in Table 3.1. It was found that a significant number of these factors are highly rated. However, site managers' propositions accomplishment are less in "efficient time management", "manpower efficiency", and "nominated supplier's control", in order of "weakness". Thus, site manager need to be cognisant of these factors, (among others), towards enhancement of efficient resources utilisation.

\section{Essential and desirable factors}

towards efficient resources utilisation Further investigations were made to ascertain the essential factors towards the accomplishment of efficient resources utilisation. It was found that out of 43 factors considered, 28 factors are essential, while 15 factors are desirable. Table 3.2 shows the order of importance of these factors with their corresponding groups abbreviated. Thus, construction site managers required being proficient in these essential factors in order to be more efficient in resources utilisation. The site manager's ability to have absolute authority and control on these essential factors during production process will significantly enhance the manager efficient performance, resources' wastes management and perpetuate stakeholders' satisfaction

Reliability and validity tests'

statistics

The reliability and validity tests' statistics of samples obtained during questionnaires survey are presented in Tables 3.3(a) to 3.3(h). Viewing the characteristics of the scale, the following facts are apparent:

\section{a) Validity test statistics}

ANOVA test was conducted to find the different in mean value of the samples; and the value obtained indicates a strong agreement between the respondents, showed that the samples share a common trait, (sig. $<0.05$ ).

Also, the validity of the results were confirmed when all the samples chisquare results registered ( $p<0.05$ ). This indicates that there is strong significant association between the variables, (samples) collected, Tables 3.3(a) to $3 \cdot 3(\mathrm{~h})$.

\section{b) Reliability test statistics:}

The Cronbach's alpha coefficient value of items ranges from o to1, and the reliability of the "overall total item coefficient" increases from o to 1, (Coakes and Steed, 2003; and Field, 2005). However, the coefficient value depends greatly on the number of items on the scale; the more the number of the items, the greater the alpha coefficient; that is, size and number of samples collected significantly affect the Cronbach's alpha coefficient ratio. The 'overall alpha' is significant between 0.7 (weak) and 1.0 (Absolute), (Field, 2005). 


\begin{tabular}{|c|c|c|c|c|c|c|c|c|c|}
\hline $\begin{array}{c}\text { A) } \\
\text { Manpower }\end{array}$ & $\%$ & $\begin{array}{c}\text { B) } \\
\text { Materials }\end{array}$ & $\%$ & $\begin{array}{c}\text { C) } \\
\text { Machinery }\end{array}$ & $\%$ & $\begin{array}{c}\text { D) } \\
\text { Cost control }\end{array}$ & $\%$ & $\begin{array}{c}\text { E) } \\
\text { Quality management }\end{array}$ & $\%$ \\
\hline $\begin{array}{l}\text { Manpower as } \\
\text { planned }\end{array}$ & 73 & $\begin{array}{l}\text { Procurement of } \\
\text { materials as planned }\end{array}$ & 79 & $\begin{array}{l}\text { Control of } \\
\text { machinery }\end{array}$ & 71 & Order cost control & 77 & $\begin{array}{l}\text { Adequate quality } \\
\text { control }\end{array}$ & 79 \\
\hline $\begin{array}{l}\text { Staff acquisition } \\
\text {----skilled }\end{array}$ & 72 & $\begin{array}{l}\text { Adequate material } \\
\text { control strategies }\end{array}$ & 72 & $\begin{array}{l}\text { Efficient machinery } \\
\text { procurement }\end{array}$ & 70 & $\begin{array}{l}\text { Purchase cost } \\
\text { control }\end{array}$ & 76 & $\begin{array}{l}\text { Achieving quality } \\
\text { predicted }\end{array}$ & 76 \\
\hline $\begin{array}{l}\text { Staff acquisition } \\
---- \text { unskilled }\end{array}$ & 71 & $\begin{array}{l}\text { Adequate stock/store } \\
\text { control }\end{array}$ & 71 & $\begin{array}{l}\text { Efficient } \\
\text { organisation of } \\
\text { machinery }\end{array}$ & 69 & $\begin{array}{l}\text { Resources cost } \\
\text { control }\end{array}$ & 74 & & \\
\hline $\begin{array}{l}\text { Team selection and } \\
\text { combination }\end{array}$ & 68 & $\begin{array}{l}\text { Efficient materials } \\
\text { organisation }\end{array}$ & 71 & $\begin{array}{l}\text { Plants output } \\
\text { prediction }\end{array}$ & 68 & $\begin{array}{l}\text { Construction cost as } \\
\text { planned }\end{array}$ & 73 & & \\
\hline $\begin{array}{l}\text { Labour productivity } \\
\text { prediction }\end{array}$ & 66 & $\begin{array}{l}\text { Efficient co-ordination } \\
\text { of material }\end{array}$ & 70 & & & $\begin{array}{l}\text { Resources cost } \\
\text { budgeted }\end{array}$ & 72 & & \\
\hline Manpower control & 66 & & & & & Holding cost control & 68 & & \\
\hline $\begin{array}{l}\text { Labour motivation } \\
\text { strategies }\end{array}$ & 64 & & & & & & & & \\
\hline$\frac{f}{\text { Time Management }}$ & $\%$ & g) & $\%$ & $\begin{array}{c}\text { i) } \\
\text { Resources } \\
\text { Procurement }\end{array}$ & $\%$ & $\begin{array}{c}\mathrm{J}, \mathrm{k}, \mathrm{l} \& \mathrm{~m} \\
\text { (Other factors) }\end{array}$ & $\%$ & & \\
\hline $\begin{array}{l}\text { Time control and } \\
\text { sequence }\end{array}$ & 73 & $\begin{array}{l}\text { Risk assessment and } \\
\text { quantification }\end{array}$ & 82 & $\begin{array}{l}\text { Integration the } \\
\text { procurements of all } \\
\text { resources }\end{array}$ & 74 & $\begin{array}{l}\text { J) project } \\
\text { Scope determinant }\end{array}$ & 75 & & \\
\hline $\begin{array}{l}\text { Adequate activities } \\
\text { control }\end{array}$ & 71 & $\begin{array}{l}\text { Efficient risk features } \\
\text { identification }\end{array}$ & 81 & $\begin{array}{l}\text { Resources source } \\
\text { selection }\end{array}$ & 68 & $\begin{array}{l}\text { K) delegation of } \\
\text { authority }\end{array}$ & 73 & & \\
\hline $\begin{array}{l}\text { Activities duration } \\
\text { scheduled }\end{array}$ & 68 & $\begin{array}{l}\text { Adequate risk } \\
\text { response against treat }\end{array}$ & 73 & $\begin{array}{l}\text { Resources } \\
\text { evaluation and } \\
\text { assessment }\end{array}$ & 67 & $\begin{array}{l}\text { L) sub- } \\
\text { Contractors control }\end{array}$ & 71 & & \\
\hline $\begin{array}{l}\text { Efficient time as } \\
\text { planned and defined }\end{array}$ & 66 & $\begin{array}{l}\text { Risk alternative } \\
\text { strategy }\end{array}$ & 68 & $\begin{array}{l}\text { Prediction of } \\
\text { procurements' } \\
\text { constraints }\end{array}$ & 66 & $\begin{array}{l}\text { M) nominated } \\
\text { supplier's control }\end{array}$ & 66 & & \\
\hline $\begin{array}{l}\text { Activities duration } \\
\text { estimated }\end{array}$ & 66 & $\begin{array}{l}\text { Emergency cover-up } \\
\text { planned }\end{array}$ & 66 & $\begin{array}{l}\text { Market condition } \\
\text { prediction }\end{array}$ & 65 & & & & \\
\hline
\end{tabular}

Table: 3.1 Ease of Accomplishment of Propositions in Rank Order of Possibilities

A) Essential factors to be accomplished in descending order of importance (Group abbreviated)

1. Construction cost as planned (Cc)

2. Efficient risk features identification (Rc)

3. Staff acquisition -----skilled (Mp)

4. Resources cost control (CC)

5. Manpower as planned ( $\mathrm{Mp}$ )

6. Procurement of materials as planned (Ma)

7. Risk assessment and quantification (Rc)

8. Sub. Contractors' control (Sc)

9. Adequate quality control (Qc)

10. Achieving quality predicted (Qc)

11. Order cost control (Cc)

12. Purchase cost control (CC)

13. Manpower control (Mp)

14. Time control and sequence (Tm)

15. Team selection and combination (Mp)

16. Efficient co-ordination of material ( $\mathrm{Ma})$

17. Resources cost budgeted (Cc)

18. Adequate risk response against threat (Rc)

19. Holding cost control- to avoid waste (CC)

20. Adequate material control strategies (Ma)

21. Integration of resources procurement (Rp)

22. Project scope determinant, (Ps)

23. Adequate stock/store control (Ma)

24. Control of machinery (Me)

25. Efficient time as planned and defined ( $\mathrm{Tm}$ )

26. Delegate of authority, (Da)

27. Activities duration scheduled (Tm)

28. Risk alternative strategy (Rc)
B) Desirable factors to be accomplished in descending order of importance (Group abbreviated)

1. Market condition prediction (Rp)

2. Staff acquisition -----unskilled (Mp)

3. Resources evaluation and assessment (Rp)

4. Labour motivation strategies ( $\mathrm{Mp}$ )

5. Plants output prediction (Me)

6. Efficient organisation of machinery (Me)

7. Emergency cover-ups planned (Rc)

8. Resources source selection (Rp)

9. Efficient machinery procurement (Me)

10. Prediction of procurement constrains ( $\mathrm{Rp})$

11. Activities duration estimated (Tm)

12. Labour productivity prediction ( $\mathrm{Mp})$

13. Efficient materials organisation (Ma)

14. Adequate activities control (Tm)

15. Nominated supplier control. (Ns)
Table 3.2 Essential and Desirable factors towards accomplishment of Efficient Resources Utilisation, in descending order of importance 
The "total Cronbach's alpha coefficient" values obtained of all the items, factors considered are found to be reliable, (apart from a factor each from the Manpower (Mp) and Materials ( $\mathrm{Ma}$ ) samples). Also, the value of the individual "Corrected item-total Correlations" is greater than 0.3, (Tables 3.3). That is: (i)The "corrected item of total correlation coefficients" of each factor >0.3.

(ii)The "overall Cronbach's alpha coefficient" is greater than all individual items "Cronbach's alpha if the item is deleted".

These statistics indicate that there are internal consistencies between the values of the samples, (data), collected.

In respect to the considered factors on manpower scenarios on accomplishment of Site Manager's proposition, the value of Cronbach's alpha coefficients of all variables is 0.726 ; if "Manpower as planned Staff acquisition
- unskilled" item is deleted, the reliability will be improved to 0.856 (Table 3.3a). Also, the "Materials factors rate of accomplishment", the total Cronbach's alpha coefficient value is 0.798 . However, if "Adequate stock control" item is deleted the value will be 0.803 , (Table 3.3b). Though, these do not indicate invalid results; the values are within acceptable range.

\begin{tabular}{|c|c|c|c|c|c|}
\hline Factors & $\begin{array}{l}\text { Corrected Item- } \\
\text { Total Correlation }\end{array}$ & $\begin{array}{l}\text { Cronbach's Alpha } \\
\text { if Item Deleted }\end{array}$ & Total Cronbach's Alpha coefficient & $\begin{array}{l}\text { Chi- Square } \\
\text { (Sig.) }\end{array}$ & $\begin{array}{l}\text { ANOVA } \\
\text { F-test (Sig) }\end{array}$ \\
\hline Manpower as planned & .625 & .656 & \multirow{7}{*}{$\begin{array}{l}\text { Total Cronbach's Alpha coefficient } \\
\text { value will be } 0.856 \text { if "Staff } \\
\text { Acquisition" item is deleted. }\end{array}$} & 0.01 & \multirow{7}{*}{0.01} \\
\hline Staff acquisition -----skilled & .464 & .694 & & 0.01 & \\
\hline Staff acquisition -----unskilled & .298 & .856 & & 0.01 & \\
\hline Team selection and combination & .761 & .608 & & 0.01 & \\
\hline Manpower control & .689 & .621 & & 0.01 & \\
\hline Labour productivity prediction & .523 & .676 & & 0.01 & \\
\hline Labour motivation strategies & .597 & .651 & & 0.01 & \\
\hline
\end{tabular}

Table 3.3a Reliability and Validity Statistics - Manpower Utilisation

\begin{tabular}{|c|c|c|c|c|c|}
\hline Factors & $\begin{array}{l}\text { Corrected Item- } \\
\text { Total Correlation }\end{array}$ & $\begin{array}{l}\text { Cronbach's Alpha } \\
\text { if Item Deleted }\end{array}$ & Total Cronbach's Alpha coefficient & $\begin{array}{l}\text { Chi- Square } \\
\text { (Sig.) }\end{array}$ & $\begin{array}{l}\text { ANOVA } \\
\text { F-test (Sig.) }\end{array}$ \\
\hline $\begin{array}{l}\text { Adequate material control } \\
\text { strategies }\end{array}$ & .563 & .765 & \multirow{5}{*}{$\begin{array}{l}0.803 \\
\text { Total Alpha coefficient when Stock } \\
\text { control item is deleted }\end{array}$} & 0.01 & \multirow{5}{*}{0.01} \\
\hline Adequate stock/store control & .451 & .803 & & 0.01 & \\
\hline $\begin{array}{l}\text { Procurement of materials as } \\
\text { planned }\end{array}$ & .690 & .721 & & 0.01 & \\
\hline Efficient materials organisation & .624 & .745 & & 0.01 & \\
\hline Efficient co-ordination of material & .600 & .757 & & 0.01 & \\
\hline
\end{tabular}

Table 3.3b Reliability and Validity Statistics - Materials Utilisation

\begin{tabular}{|c|c|c|c|c|c|}
\hline Factors & $\begin{array}{l}\text { Corrected Item- } \\
\text { Total Correlation }\end{array}$ & $\begin{array}{l}\text { Cronbach's Alpha } \\
\text { if Item Deleted }\end{array}$ & $\begin{array}{l}\text { Total } \\
\text { Cronbach's Alpha coefficient }\end{array}$ & $\begin{array}{l}\text { Chi- Square } \\
\text { (Sig.) }\end{array}$ & $\begin{array}{l}\text { ANOVA } \\
\text { F-test (Sig.) }\end{array}$ \\
\hline Plants output prediction & .589 & .635 & \multirow{4}{*}{.734} & 0.01 & \multirow{4}{*}{0.304} \\
\hline Control of machinery & .497 & .690 & & 0.01 & \\
\hline Efficient machinery procurement & .590 & .635 & & 0.01 & \\
\hline $\begin{array}{l}\text { Efficient organisation of } \\
\text { machinery }\end{array}$ & .441 & .720 & & 0.01 & \\
\hline
\end{tabular}

Table 3.3c Reliability and Validity Statistics - Machinery Utilisation 


\begin{tabular}{|l|c|c|c|c|}
\hline \multicolumn{1}{|c|}{ Factors } & $\begin{array}{c}\text { Corrected Item- } \\
\text { Total Correlation }\end{array}$ & $\begin{array}{c}\text { Cronbach's Alpha } \\
\text { if Item Deleted }\end{array}$ & $\begin{array}{c}\text { Total Cronbach's Alpha } \\
\text { coefficient }\end{array}$ & $\begin{array}{c}\text { ANOVA } \\
\text { F-test (Sig.) } \\
\text { (Sig.) }\end{array}$ \\
\hline Construction cost as planned & .771 & .869 & 0.01 \\
\hline Resources cost control & .776 & .866 & .894 & 0.01 \\
\hline Resources cost budgeted & .765 & .868 & 0.01 \\
\hline $\begin{array}{l}\text { Purchase cost control } \\
\text { Order cost control }\end{array}$ & .713 & .878 & 0.304 \\
\hline $\begin{array}{l}\text { Holding cost control - (to avoid } \\
\text { waste) }\end{array}$ & .710 & .879 & 0.01 \\
\hline
\end{tabular}

Table 3.3d Reliability and Validity Statistics - Cost Control

\begin{tabular}{|l|c|c|c|c|c|}
\hline \multicolumn{1}{|c|}{ Factors } & $\begin{array}{c}\text { Corrected Item- } \\
\text { Total Correlation }\end{array}$ & $\begin{array}{c}\text { Cronbach's } \\
\text { Alpha if Item } \\
\text { Deleted }\end{array}$ & $\begin{array}{c}\text { Total Cronbach's Alpha } \\
\text { coefficient }\end{array}$ & $\begin{array}{c}\text { Chi- } \\
\text { Square } \\
\text { (Sig.) }\end{array}$ & $\begin{array}{c}\text { ANOVA } \\
\text { F-test (Sig) }\end{array}$ \\
\hline Adequate quality control & .518 & 664 & & 0.01 & .009 \\
\hline Achieving quality predicted & .518 & .671 & .676 & 0.01 & .009 \\
\hline
\end{tabular}

Table 3.3e Reliability and Validity Statistics - Quality in Construction

\begin{tabular}{|l|c|c|c|c|c|}
\multicolumn{1}{|c|}{ Factors } & $\begin{array}{c}\text { Corrected Item- } \\
\text { Total Correlation }\end{array}$ & $\begin{array}{c}\text { Cronbach's Alpha } \\
\text { if Item Deleted }\end{array}$ & $\begin{array}{c}\text { Total Cronbach's Alpha } \\
\text { coefficient }\end{array}$ & $\begin{array}{c}\text { Chi- Square } \\
\text { (Sig.) }\end{array}$ & $\begin{array}{c}\text { ANOVA } \\
\text { F-test (Sig) }\end{array}$ \\
\hline $\begin{array}{l}\text { Efficient time as planned and } \\
\text { defined }\end{array}$ & .721 & .801 & & 0.01 & 0.01 \\
\hline Time control and sequence & .629 & .825 & .848 & 0.01 & 0.01 \\
\hline Activities duration estimated & .652 & .823 & & 0.01 \\
\hline Activities duration scheduled & .648 & .822 & & 0.01 \\
\hline Adequate activities control & .668 & .814 & & \\
\hline
\end{tabular}

Table 3.3f Reliability and Validity Statistics - Time Management

\begin{tabular}{|l|c|c|c|c|c|}
\hline \multicolumn{1}{|c|}{ Factors } & $\begin{array}{c}\text { Corrected Item- } \\
\text { Total Correlation }\end{array}$ & $\begin{array}{c}\text { Cronbach's } \\
\text { Alpha if Item } \\
\text { Deleted }\end{array}$ & $\begin{array}{r}\text { Chi- } \\
\text { Cronbach's Alpha coefficient }\end{array}$ & $\begin{array}{c}\text { ANOVA } \\
\text { Square } \\
\text { (Sig.) }\end{array}$ & 0.01 \\
\hline $\begin{array}{l}\text { Efficient risk features (Sig.) } \\
\text { identification }\end{array}$ & .627 & .837 & 0.01 & 0.00 \\
\hline $\begin{array}{l}\text { Risk assessment and } \\
\text { quantification }\end{array}$ & .573 & .850 & .856 & 0.01 \\
\hline $\begin{array}{l}\text { Adequate risk response against } \\
\text { treat }\end{array}$ & .854 & .777 & & 0.01 \\
\hline Risk alternative strategy & .761 & .805 & & 0.01 \\
\hline Emergency cover-up planned & .592 & .857 & & 0.00 \\
\hline
\end{tabular}

Table 3.3g Reliability and Validity Statistics - Risk in Construction

\begin{tabular}{|c|c|c|c|c|c|}
\hline Factors & $\begin{array}{l}\text { Corrected Item- } \\
\text { Total Correlation }\end{array}$ & $\begin{array}{c}\text { Cronbach's } \\
\text { Alpha if Item } \\
\text { Deleted }\end{array}$ & $\begin{array}{c}\text { Total } \\
\text { Cronbach's Alpha coefficient }\end{array}$ & $\begin{array}{c}\text { Chi- } \\
\text { Square } \\
\text { (Sig.) }\end{array}$ & $\begin{array}{c}\text { ANOVA } \\
\text { F-test (Sig.) }\end{array}$ \\
\hline $\begin{array}{l}\text { Integration of all resources } \\
\text { procurement }\end{array}$ & .510 & .712 & \multirow{5}{*}{.751} & .001 & \multirow{5}{*}{.001} \\
\hline Resources source selection & .575 & .688 & & .001 & \\
\hline $\begin{array}{l}\text { Resources evaluation and } \\
\text { assessment }\end{array}$ & .523 & .704 & & .001 & \\
\hline Market condition prediction & .582 & .681 & & .001 & \\
\hline $\begin{array}{l}\text { Prediction of procurements' } \\
\text { constraints }\end{array}$ & .423 & .748 & & .001 & \\
\hline
\end{tabular}

Table 3.3h Reliability and Validity Statistics - Resources Procurement 


\section{Interview Reports}

The following sub sections present the facts summarised from the qualitative interview survey conducted:

\section{Causes of Site manager's \\ inefficiency towards \\ accomplishment of optimal \\ resources utilisation during construction production process}

- Short initial planning period. There are often short lead-in periods to execute projects. This results in inadequate time to plan resources accurately and in logical sequence at the inception of the project.

- Short project delivery time expectation. In most cases, resources optimal utilisation and adequate wastes reduction are not normally taken into consideration where projects are expected to be delivered speedily. That is, when there is urgency in the need of project product(s). If the project design team and client are anxious over the project's end product, they are often less concerned with construction problems. Consequently, less attention is normally paid to resources utilisation and wastefulness

- Modification during project execution. Alterations either by the design team or the client often cause construction resources wastefulness unconsciously, deliberately or coincidentally.

- Skeletal production information provided by the design team. When inadequate or skeletal production information is provided by the design team to commence project work, it makes the project scope unclear to the site personnel. This leads to time waste and affect efficient resources utilisation during the project in progress.

- Aesthetics keenness and over assumption of the design team. The design team are often after aesthetics with less consideration of resources utilisation, cost and time of project construction. Sometimes provide complex and fanciful design packages; based on the assumption that the production team should be able to interpret the concept for project execution.

- Shortage of skilled workers. Among the major problems in the construction industry currently is the inability to engage experienced and skilled labour for work. Lack of skilled workers results in engaging of semi-skilled workers who are somewhat inefficient in resources utilisation. This often causes re-work, (cost and time wastes), in order to achieve the predetermined quality. This problem is becoming a major issue in the construction industry globally.

Factors that will enhance the Site manager in accomplishment of optimal resources utilisation during construction production process

- Availability of adequate time for detailed production information preparation. To facilitate construction work and the minimisation of alterations and modifications during construction production process, the design team needed sufficient time to produce explicit and adequate production information. Factors that could cause resources inefficient utilisation during the construction phase required to be identified and corrected during the design stage. Design concept precision and adequate prescription will significantly reduce alterations and modifications during the construction phase. In respect, less resource wastefulness (materials, labour or machinery wastes) will be incurred.

- Prefabricated materials and panellised components. There is need to enhance off-site prefabrication of construction project components, especially materials' components. Precast materials components brought to site for "fixing only" will minimise labour utilisation, and enhance resources' wastes minimisation and efficient utilisation. In respect, these will enhance the site managers' efficient performance and achievement of propositions.

- Experience and efficiency of Suppliers and Sub contractors. Sub-contractors need to be appointed based on both experience and efficiency. Engaging those that had worked with the companies, having a good track record of competency is essential, In addition, the sub contractors and suppliers that have worked on similar jobs previously are usually efficient in resources utilisation, leading to optimal project propositions' achievement.

- Availability of contractor design team. The availability of an internal design team enhances resources' efficient utilisation and site managers' efficient performance. The team will tend towards working on construction project target, scope, delivery time, cost effectiveness, quality and resources' wastes minimisation.

\section{- Effective integration of time and cost} saving contrasts. Time and cost are often in contrasts, and in several situations, the project construction cost compensates for targeted project delivery time. Thus, for efficient resources utilisation, site managers need to balance the effect of delivery time on cost which could perpetuate resources wastefulness.

- Clear and explicit production information. A project concept properly designed with explicit specifications, reduces alterations, modifications, and time for interpretation during construction phase; and there will be less resource wastefulness, (materials, manpower, and machinery). However, when specifications are not properly detailed, it leads to frequent requests for interpretation, waste site managers' time and hinders the construction manager's efficiency and optimal proposition achievement. 
- Availability of efficient skilled workers. The availability of skilled workers to minimise utilisation of semi-skilled or inexperienced workers is paramount towards achievement of site manager and construction project's propositions. The shortage of skilled workers and utilisation of semi-skilled workers often results in re-work and resources wastefulness to achieve the predetermined site managers' proposition. Site manager need to possess adequate labour marketing skills to achieve project propositions. The industry and government need to place more emphases towards minimisation of this predicament.

- Appropriate procurement system. Adoption of an appropriate procurement system enhances the accomplishment of project propositions. For example, "design and build" and "package deal" procurement systems often yield less resource wastefulness in comparison with other procurement systems. If the design - build organisation produces production information and performs the construction operation, the site manager in the organisation will be able to achieve an enhance project propositions; modalities of accomplishing efficient resources utilisation would have be recognised and in-built into the design concept.

- Exact work to appropriate person or team. To achieve the predetermined, expected site manager's or project proposition, there is a need to engage efficient and effective sub-contractors and suppliers. The engagement or project award need to base on efficiencies, probably, those who had already worked for the organisation, or those who have work in similar project previously. These will enhance the efficient utilisation of construction resources. Machinery and equipment supplier work should be given to those who have significant knowledge, equipment, and workers. An enhanced efficiency of resources uti- lisation is achievable by selecting the right sub-contractors and suppliers.

- Adoption and implementation of prefabrication and modular construction systems. Prefabrication and delivery of construction resources on site for fixing and assembly enhance site manager's performance and efficient resources utilisation, In this regard, resources wastes will be at minimal; the majority of resources' wastes minimisation would have been done offsite, and the few unavoidable wastes would be due to a few components that require trimming - to -fit.

\section{- Adequate planning period at project} inception. The urgent need of a project and lack of sufficient planning before the project commences sometimes leads to time waste and hinders efficient resources utilisation. Thus, an adequate planning period before any project commences will significantly enhance site managers' efficient performance during production process.

Based on the findings obtained in this research quantitative survey, (that is, the high accomplishment rate of many factors, presented in Table 3.1), it could be deduced that resources wastefulness is remotely related to the achievement of Site manager's propositions, thus, this indicates that:

\section{"A project could be completed with high accomplishment of Construc- tion site manager's proposition with lots of resources wastefulness"}

Thus, this fact, driven the question that: "Why resources wastages are high when achievement of site managers' propositions are high during construction production process?"

Rationally, if there is unlimited money and time for a project, its management is easier. However, several projects have timeframes, (Ferner, 1980; and Reh, 2005), and are to be constructed within a budgeted cost, (PMI, 2005; and APM,
2006). Thus, effective and efficient time and cost management are paramount for project success accomplishment. Towards optimal accomplishment of project objectives during construction production process, the site manager is required to perform the following success criteria effectively:

i. specification of project objectives and plans including effective delineation of scope, budget, schedule, set performance requirements, and selection of efficient project workers;

ii. maximisation of resource utilisation through efficient procurement of labour, materials, and equipment in accordance to the defined schedule and plan;

iii.implementation of various operations through proper co-ordination, monitoring and controls; and effective planning, designing, estimating, contracting and constructing of the entire process; and

iv.development of effective communications and mechanisms for resolving conflicts among the various participants.

In conceptualisation of these stated site manager success factors, this study investigated factors that will significantly enhance the optimal utilisation of construction resources and established:

i. the significant factors towards accomplishment of efficiency;

ii. the factors that impair resources wastes reduction during production processes.

iii.the factors that causes the site managers' weaknesses (flaws) on efficient construction resources utilisation.

iv.the factors that will strengthen site managers towards efficient resources utilisation,

These factors will not only enhance the site managers' efficient performance, but also will minimise resources' wastes and augment stakeholders' satisfaction. 


\section{Conclusion and \\ Recommendations}

This paper presented factors that will significantly enhance efficient resources utilisation by identifying several variables that required extra attention of the construction site managers during construction production process.

Both questionnaire quantitative and qualitative in-depth interview research surveys were conducted to obtain data and information from experienced constriction site managers within the UK construction sector. The acquired quantitative and qualitative data obtained were analysed using SPSS and NVivo statistics software respectively.

Many factors investigated were found to be essential and significantly important towards resources' wastes minimisation and enhancement of site managers' predetermined and project objectives accomplishment. However, there are clear indications that more efforts are required in some areas including: "efficient time management", "manpower efficiency", and "nominated supplier co-ordination". It was found that among various causes of inability to optimally achieve the predetermined site managers' propositions include: short initial planning period, short project delivery time expected, and skeletal production information often provided by the design team to commence the project. This paper suggest that, to achieve construction site managers' propositions significantly, the following are essential: effective integration of time and cost saving contrasts; adoption and implementation of prefabrication and modular construction systems; and, availability of adequate planning period at project inception.

Since, construction industry need to reexamine the way it produces its products in order to reduce wastes, and to enhance the stakeholders satisfaction and constructors profit, as being feasible in other sectors, (the industrial and service sectors); so, there is a significant requirement for the construction management team to re-appraise the identified "weaknesses" in this paper. In addition, to capitalise on its "strengths" and "opportunities" as a way to guide against any opposing "threat" that could lead to inefficient resources utilisation and resources wastefulness.

The identified and established facts presented in this paper will enhance efficient resources utilisation, resources' wastes minimisation and construction site manager's performances during construction production process.

\section{References}

APM, (2006), Association of Project

Management Body of Knowledge, 5 th ed. UK:

Association of Project Management

Blair, G. M. (1993), Basic management skill:

Personal time management for busy managers, IEE Engineering Management Journal Bimonthly, Oct. 1991, to April, 1993. http://www.see.ed.ac. uk/ gerard/Management/art2.html, Bryman, A. and Cramer, D. (2005), Quantitative analysis with SPSS 12 and 13: A guide

for social scientist, London: Routledge.

Bryman A and Cramer D, (2005),

Quantitative analysis with SPSS 12 and 13: A guide for social scientist, London: Routledge.

Coakes, S. J. and Steed, L. G., (2003), SPSS Analysis without anguish: Version 11.0 for windows. Australia: Kyodo Printing Co ltd.

Egan, J., (1998), Rethinking construction report: The scope for improving the quality and efficiency of the UK construction. UK: DETR.

http://www.ciob.org.cn/resources/ download/Rethinking\%20 construction\%2othe\%2oegan\%2oreport. pdf. (Accessed on 28 May, 2006)

Ferner, J.. (1980), Successive time management. USA: John Wiley and Sons. Field, A., (2005), Discovery statistics using SPSS for window. London: Sage Publication.
Haughey, D., (2009), An introduction to project management. (Online), Project Smart.co.uk, (online), (Accessed 04 January, 2009); http://www.proje`ctsmart.co.uk/ introduction_to_project_management. html

Hendrickson, C., (2009), Project management for construction: fundamental concepts for owners, engineers, architects and builders, Chapter 2, Version 2.2. (e-book)

Hillson, D., and Murray-Webster, R., (2005), Understanding and managing risk attitude. $2^{\text {nd }}$ ed. UK: Gower Publishers.

McGeorge, D. and Palmer, A., (2002), Construction management: new direction. $2^{\text {nd }} \mathrm{ed}$.

UK: Oxford Press.

Newcombe, R., Langford, D. and Fellow R., (2003), Construction management, vol. 1. UK: CIOB

PMI, (2005), A guide to the Project Management Body of Knowledge, $3^{\text {rd }}$ ed. PMI

standard committee. Maryland, USA: PMI Publishing Division.

Rafele, C., Hillson, D. and Grimaldi, S., (2005), Understanding project risk exposure,

the two dimensional risk breakdown matrix, PMI Global Proceedings, 2005,

Edinburgh, Scotland

http://www.risk-doctor.com/pdf-files/pmie-rbmpaper.pdf

Reh, F. J., (2005), Managing time and schedule. (Online). Project Management 101 ,

Part 3, (Accessed 03 May, 2006). http://management.about.com/cs/ projectmanagement/a/PM101c.htm

Sapsford, R., (1999), Survey research. London: SAGE publication ltd.

Sarantakos, S., (2001), Social research. $2^{\text {nd }}$ ed. NY, USA: Palgrave Publisher.

Sapsford, R. and Jupp, V., (1996), Data collection and analysis. London: Sage

Publications in Association with Open University.

Silverman, D., (2000), Doing qualitative research: A practical handbook. London: Sage Publications.

Wideman, R. M., (l986), The PMBOK report: PMI Body of Knowledge Standard. Project Management Journal, Vol. 17(3), 15-24. 